\title{
EDITORIALS
}

\section{Paying for migrant healthcare}

\author{
Recent research allows no easy headlines
}

\author{
Johanna Hanefeld lecturer ${ }^{1}$, Neil Lunt reader ${ }^{2}$, Richard Smith dean ${ }^{1}$ \\ ${ }^{1}$ Faculty of Public Health and Policy, London School of Hygiene and Tropical Medicine, London, UK ; ${ }^{2}$ Department of Social Work and Social Policy, \\ University of York, York, UK
}

Publication of research commissioned by the Department of Health on visitor and migrant access to the National Health Service (NHS) has put the issue of so called "health tourism"-where people travel with the intention of obtaining treatment to which they are not entitled for free on the NHS - centre stage. ${ }^{1}$ Earlier this year the government consulted on policy proposals for migrant access and financial contribution to the NHS in England. ${ }^{2}$ These included a migrant health levy on non-EEA (European Economic Area) visitors of $£ 200$ annually. The Draft Immigration Bill published earlier this month $^{3}$ makes legal provision for such a surcharge.

The reports published this week by the Department of Health examine a wide spectrum of use of the NHS by visitors, including British expatriates and EU citizens, as well as irregular migrants and "health tourists." ${ }^{4}$ Despite media announcements by the secretary of state for health that these groups taken together cost the NHS £2bn a year, ${ }^{1}$ the report, which places several caveats on the validity of its data and is careful not to overstate its claims, estimates that in the region of 10000 patients would meet the definition of a "health tourist," costing around $£ 70 \mathrm{~m}$ a year. ${ }^{5}$ This compares with, for example, $£ 305 \mathrm{~m}$ of chargeable costs incurred by EEA citizens, which could be reclaimed by the government under EU agreement, and British expatriates living outside the EEA, which are estimated to account for $£ 50 \mathrm{~m}$ annually.

The qualitative report highlights the complexity of issues involved in the pursuit of such reimbursement and charges from patients, including when these might be EU citizens or British expatriates living abroad. There is a clear sense among clinicians that they do not want to be involved in the clarification of entitlements of patients to care. It highlights the challenges in administering and implementing current regulation, such as those in relation to entitlements for patients from the European Union. In particular, ensuring that patients who are not legitimately registered with the NHS are identified when they present to secondary or tertiary care would probably require a change in current remit of NHS staff. The findings highlight a perverse incentive - those NHS trusts proactive in charging patients have greater debt than those that do not.
The analysis omits the costs of administering stricter policies and monitoring of NHS use by migrants and visitors. Given the wide range of issues that this recent research touches on, it remains unclear what a streamlined efficient policy and administration might look like. Certainly it would require changes to the culture of the NHS, its way of working, and its management structures. The Home Office's impact assessment of the draft Immigration Bill estimates the income resulting from a government surcharge for migrants accessing the NHS as nearly $£ 2$ bn over 10 years; the administrative cost over the same period of collecting this money is quoted as $£ 3 \mathrm{~m}$. ${ }^{6}$ The complexities that have been unearthed by the government's own published research make it seem questionable whether the cost of such a policy has really been considered.

A recent OECD (Organisation for Economic Co-operation) report on migration of inactive EEA citizens gives little support to the idea that intent to obtain health services is a major motivation for travel and migration. ${ }^{7}$ It concluded that within the EEA, healthcare consumption linked to non-active EU mobile citizens is probably small compared with the size of total health spending ( $0.2 \%$ on average) and that most mobile EEA citizens migrated for work.

While the current UK debate has focused on the costs of visitors and migrants to the NHS, it has largely ignored wider issues of patient mobility. An emphasis of the government's consultations is the principle that "everyone makes a contribution" and has "full ties and permanent relationships that justify inclusion in our social welfare model." Affirmation of such entitlements is not something that the UK can deal with alone. Despite considerable limitations of data, it is evident that many more people — and patients—are travelling, including with the explicit intention of seeking treatment (whether as "health tourists" trying to fly in and out and evading payment or as medical tourists seeking cheaper, better, or simply accessible treatment for which they pay). ${ }^{8}$ While we have limited information on exact numbers of patients travelling and levels of expenditure, figures from the UK International Passenger Survey suggest a growing number of UK patients travel abroad to seek treatment. ${ }^{9}$ Similarly, the experience of Spain and Greece has probably had implications for the UK health system as more British 
expatriates might be returning to the UK for NHS treatment as Spanish and Greek services become harder to access. ${ }^{9} 10$

Patient mobility also has other dimensions. There is incidental evidence of UK patients returning from treatment abroad with complications or infections. ${ }^{11}$ These clearly highlight not only possible costs but also risks to patients and public health and ethical challenges that are inherent in patient mobility. These issues are not covered in any of the policy and research documents highlighted and deserve a fuller hearing in the current discussion around entitlement to services. While raising a levy and new systems of regulation and monitoring attempt to tackle issues, they seem unlikely to be resolved by action of one country's government alone but rather might require countries working together through bodies such as the World Health Assembly.

Competing interests: We have read and understood the BMJ Group policy on declaration of interests and declare the following interests: None.

Provenance and peer review: Commissioned; not externally peer reviewed.
1 The true cost of health tourism: foreigners using NHS cost Britain up to £2billion a year, government report reveals .... up to 100 times more than thought. Daily Mail 22 October 2013. www.dailymail.co.uk/news/article-2470994/TRUE-cost-health-tourism-Foreignerscost-NHS-2BN-year.html.

2 Sustaining services, ensuring fairness. A consultation on migrant access and their financial contribution to NHS provision in England. Department of Health, 2013. http://consultations. dh.gov.uk/overseas-healthcare/migrant_access.

3 Immigration Bill (HC Bill 110). www.publications.parliament.uk/pa/bills/cbill/2013-2014/ 0110/cbill_2013-20140110_en_1.htm.

4 Creative Research. Qualitative assessment of visitor and migrant use of the NHS in England. Observations from the Front Line. October 2013.

5 Quantitative assessment of visitor and migrant use of the NHS in England exploring the data. Main Report. Prederi, October 2013.

6 Home Office Impact Assessment. Regulating migrant access to health services in the UK. HO 0095. October 2013. www.parliament.uk/documents/impact-assessments/IA1324F.pdf.

7 European Commission. Impact of mobile EU citizens on national social security systems. 14 October 2013. http://ec.europa.eu/social/main.jsp?langld=en\&catld=89\&newsld=1980\& furtherNews=yes.

8 Lunt N, Smith R, Exworthy M, Green ST, Horsfall D, Mannion R. Medical tourism: treatments, markets and health system implications: a scoping review. Directorate for Employment, Labour and Social Affairs, OECD, 2011.

9 Hanefeld J, Horsfall D, Lunt N, Smith R. Medical tourism: a cost or benefit to the NHS? PLOS ONE doi:10.1371/journal.pone.0070406.

10 Arie S. Briefing. Are migrant patients really a drain on European health systems? BMJ 2013;347:f6444.

11 Rogers BA, Aminzadeh Z, Hayashi Y, Paterson DL. Country-to-country transfer of patients and the risk of multi-resistant bacterial infection. Clin Infect Dis 2011;53:49-56.

Cite this as: BMJ 2013;347:f6514

(c) BMJ Publishing Group Ltd 2013 